\title{
The impacts of climate change on genetic diversity
}

\author{
Aynur DEMIR *1 \\ ORCID: 0000-0002-7856-2789
}

${ }^{1}$ Aksaray University, Department of Urbanisation and Environmental Problems, Aksaray, Turkey

\begin{abstract}
In this research, the destruction caused by climate change on genetic diversity has been demonstrated with solid examples. The consequences of the destruction on the genetic levels are discussed with concrete examples. In the study, the data obtained from the results of 40 printed publications were evaluated by correlation analysis. With these data, the importance of genetic diversity, the effect of climate change on genetic diversity, the models used to determine the relationship between climate and genetic diversity, genetic losses and protection measures were evaluated. It is noteworthy that embedded methods, in which ecological models are integrated into climate models, have been used in determining the relationships between climate and genetic diversity, especially in recent years. It is firstly necessary to detect genetic losses, genetic shifts and variations, and to reveal their future projections. These projections play a decisive role in taking effective protection measures against climate change.
\end{abstract}

Keywords: climate change, genetic diversity, ecological nice models, climate models

\section{İklim değişikliğinin genetik çeşitlilik üzerine etkisi}

\section{Özet}

$\mathrm{Bu}$ araştırmada iklim değişikliğinin genetik çeşitlilik üzerinde yarattı̆̆ı tahribat somut örneklerle ortaya konmuş ve sonuçları somut örneklerle tartışılmıştır. Araştırmada 40 basılı yayının sonuçlarından elde edilen veriler korelasyon analizi ile değerlendirilmiştir. Bu verilerle genetik çeşitliliğin önemi, iklim değişikliğinin genetik çeşitlilik üzerine etkisi, iklimle genetik çeşitlilik arasındaki ilişkileri belirlemede kullanılan modellemeler, genetik kayıplar ve koruma önlemleri değerlendirilmiştir. Iklimle genetik çeşitlilik arasındaki ilişsileri belirlemede özellikle son yıllarda ekolojik modellerin iklim modellerine entegre edildiği bütünleşik yöntemlerin kullanıldığı dikkat çekmektedir. Özellikle genetik kayıpların, genetik kaymaların ve varyasyonların saptanmasında ve gelecek projeksiyonlarının ortaya konması gerekmektedir. Bu projeksiyonlar iklim değişikliğine karşı etkin koruma önlemlerinin alınmasında önemli rol oynamaktadır.

Anahtar kelimeler: iklim değişikliği, genetik çeşitlilik, ekolojik niş modelleri, iklim modelleri

\section{Introduction}

In the 21 st century, rapid changes in climate systems are putting increasing pressure on biodiversity systems. The biodiversity crisis, which has been experienced five times in the last 500 million years, caused the extinction of $76 \%$ of living species in that period as the major cause [1]. The impact of climate change on biodiversity are not limited to the extinction of species. Factors such as temperature increases, precipitation irregularities, increases in extreme climate events, and consequently the melting of glaciers and rising of sea levels affect biodiversity at all levels such as the genetic level to ecosystems and even biomes (large life zones such as tropical rainforests, savannas, and tundras) [2]. It causes biodiversity to be exposed to additional stresses.

\footnotetext{
* Corresponding author / Haberleşmeden sorumlu yazar: Tel.: +905437246300; Fax.: +905437246300; E-mail: aynurdemir@ aksaray.edu.tr

(C) Copyright 2021 by Biological Diversity and Conservation Received: 05.12.2021; Published: 15.12.2021
} 
According to the research conducted by [3], unless strategic measures are taken to reduce climate change, there will be wide-scale shrinkage in biodiversity. For example, $60 \%$ of plants and $35 \%$ of the animals will disappear. This is the most striking indicator that the process called the $6^{\text {th }}$ extinction crisis can be experienced, [4] which is confirmed by the latest report of IPCC [5].

The impact of climate change on biodiversity occurs at various levels such as the effects on gene, species, ecosystem, and functional diversity (figure 1). Since each level is related to each other, damage on one level breaks the entire system. Genetic losses cause changes in gene pool and frequencies. It directly effects species diversity. The impact of climate change on species and populations appears in the form of loss of species, phonological changes, invasive species, adaptation and migration, and changes in geographical distribution. The balance between the ecosystem factors and different dominating species can be widely effected by climate change. For example, tree biota provides habitat for numerous fungi, and lichens, small and large animals, and also herbaceous plants. So, the loss of tree biota will effect all the populations that make up a forest ecosystem [6].

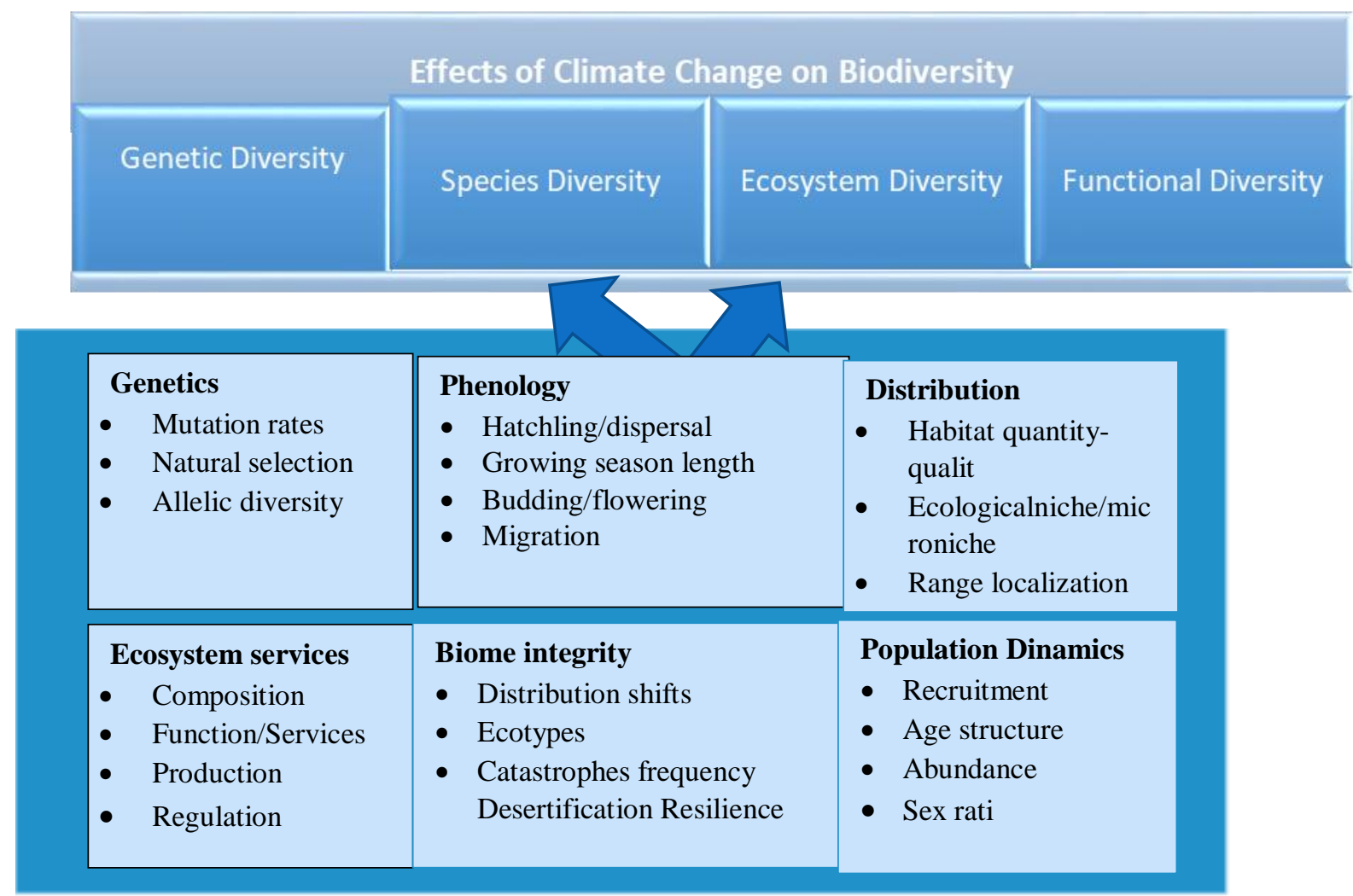

Figure 1. Impact of climate change on biodiversity levels

As it can be seen, there is a reciprocal relationship between the basic components of biological diversity. The loss of species or genetic makeup of populations negatively effects the productivity and sustainable use of ecosystems. At the same time, changes in ecosystems cause losses in species and genetic diversity. The magnitude of losses is great especially in case of endemic species and sensitive ecosystems.

Genetic diversity is the main source for evolution; however, few researches have evaluated the effects of climate change on gene diversity. Therefore, the research has focused on the effects of climate change on genetic diversity. The study sought answers to the following questions: Why should genetic diversity (intraspecies and interspecies) of climate change be investigated? How does climate change affect genetic diversity? How to investigate the impact of climate change on gene diversity? What needs to be done for the future? The answers to these questions are discussed using the concrete data in the literature. In addition, the importance of including genetic diversity when evaluating the effects of climate change was emphasized.

\section{Materials and methods}

Using the web of sciences in the research, 56 articles published between 2009-2021 were determined by using the key sentence of the impacts of climate change on gene diversity. 40 (n) studies were used in the study, 
and 16 studies were eliminated because they did not match the keywords. The studies used were evaluated with a systematic internal consistency. In this assessment:

1. Distribution of the publications in which the keyword is used by year: It is used to reveal the importance of the subject.

2. Secondly, the effect of climate on genetic diversity was surveyed. Genetic losses and their consequences are discussed with concrete, species-based examples.

3. Third, the studies were examined methodologically. It was determined by the methods used to investigate the effects of climate change on genetic diversity.

4. In the fourth stage, what need to be done for the future was discussed in terms of the protection of gene resources.

Correlation analysis was used to determine the relationships between variables. Pearson correlation were calculated using IBM SPSS Statistics 20 software. The statistical significance was shown as $* * \mathrm{P}<0.01$ and $* \mathrm{P}<0.05$ level (2-tailed).

\section{Results}

\subsection{The importance of genetic diversity and impacts of climate change on gene diversity}

Out of 40 works investigating the importance of genetic diversity in this research, 7 are reviews and 33 are resourch articles (figure 2). In the majority of research articles mainly focused on the effect of climate change on species. Spatial shifts of species in the face of climate change, geographical distribution, adaptation processes, genetic variations and their effects on evolutionary processes are explained. Particularly, the importance of gene diversity in terms of evolution has been emphasized in studies. Genetic diversity is considered as the main ingredient of evolution, and it has been stressed that evolution provides a conservation area for genetic material.

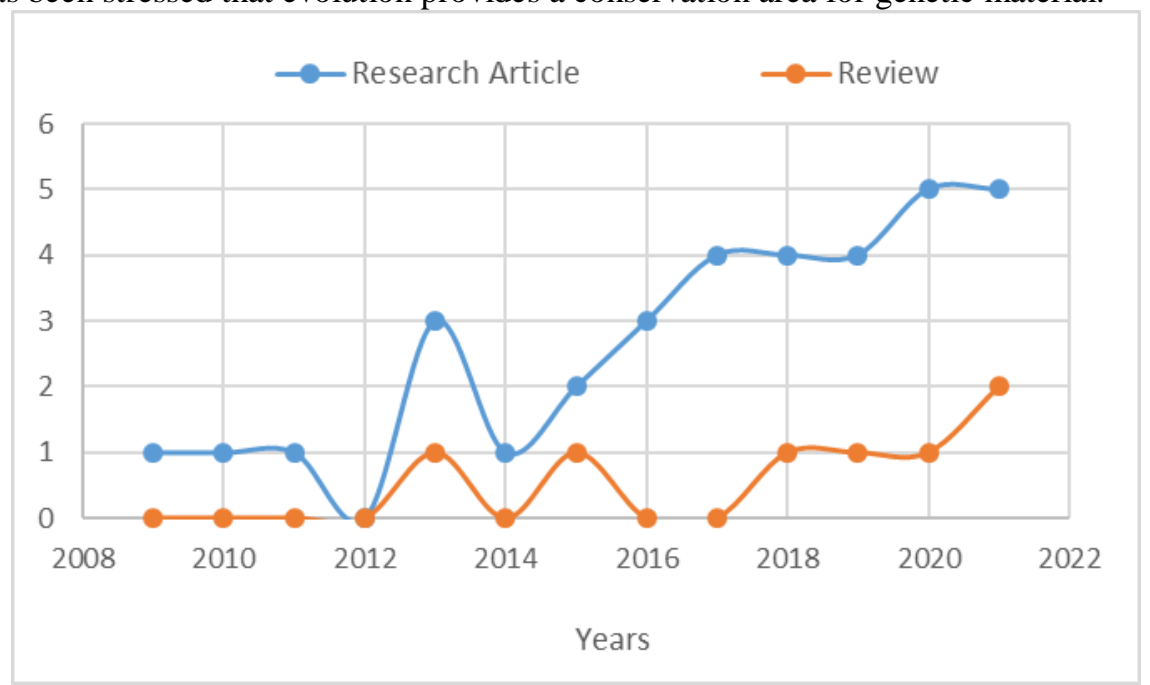

Figure 2. Distribution of publications used in the research by year

Therefore, identifying populations and species that may be more fragile to climate change is important. But, so far, genetic diversity has been overlooked in assessing the effects of climate change. Whereas genetic diversity plays an important role in determining the capacity of populations and species to genetically adapt to climate change. The responses and adaptation capacities of living things to climate change are quite different.

In terms of biodiversity, the identification of future losses may be possible by detecting losses of genetic diversity in particular. In this context, the loss of biodiversity mainly depends on the magnitude of the loss in genetic diversity, which in turn depends on the amount of loss in genetic information [7]. Genetic diversity is the guarantee of the continuity of the species. Changing conditions outside the world of living things can cause significant changes in the functioning of genes, which in turn effects diversity. Mutation, gene flow, genetic drift, natural selection, preferential mating, and epigenetic changes lead to the emergence of genetic variety $[8,9]$. In the natural process, these differences cause the species to differ as well. However, changing climatic conditions can effect these mechanisms and cause unnatural changes in the functioning of genes. It negatively effects genetic diversity and the gene pool. As a result, the loss of gene brings along the loss of species. However, the effect at the genetic level depends on whether the species can adapt to changing climatic conditions. Living things adapt to changing conditions genetically through mutation. However, if the change is rapid, genetic adaptation becomes difficult $[2,10]$. It may lead to evolutionary adaptations in the species. As seen in the results of the research, it is noteworthy that the studies conducted in recent years have focused on genetic adaptations (fig 3). In this context, Genetic diversity is also effective in the evolutionary process of 
species. The richness of intraspecies genetic diversity increases the resistance of species to climate change. But, low genetic richness reduces evolutionary resistance in the species [8,9].

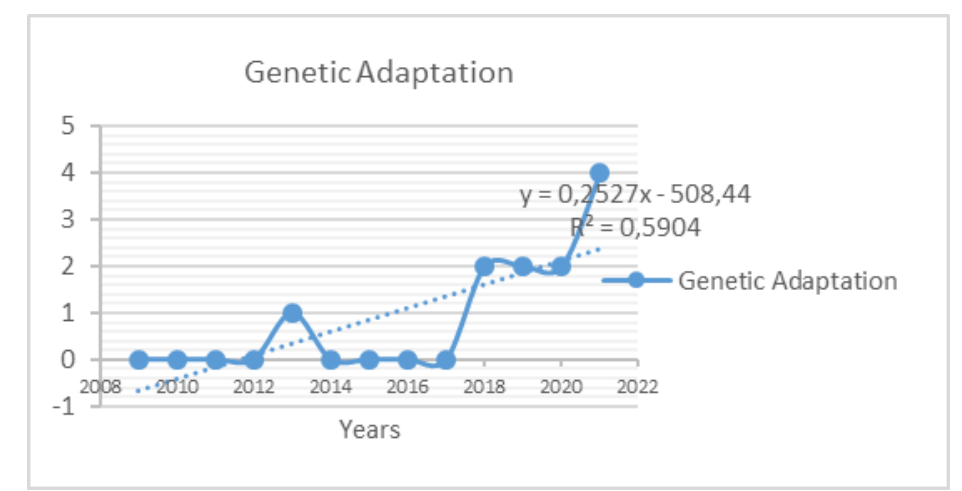

Figure 3. Publications on the impact of climate change on the genetic adaptation of species

The results of the analysis showed that genetic diversity is seriously affected by climate change. Especially in studies conducted at the species and population level, it has been determined that intraspecific variations lead to genetic variations and increase intraspecies homogeneity [10,11]. This leads to losses in gene diversity and gene pool and reduces resistance to climate change. This has been clearly demonstrated in the studies that are the subject of this research.

Research reveals a lot of evidence that species have undergone evolutionary adaptations to climate change. This evidences are evident in research based on species diversity. The research on the impacts of climate change on species has been increasing, especially since 2016 (fig 4). This allows to determine the genetic relationship with the climate, and the genetic response of the species can be evaluated. For example, In the UK, the daphnia (Daphnia magna) has evolved to cope with higher thermality [12]. Between the 1960s and 2000s, and cornflower (Centaurea cyanus) traits have changed in response to warmer springs across northern France [13]. Another example is anadromous Pink salmon (Oncorhynchus gorbuscha). In this species, it was determined that evolutionarily early migration took place and there was a decrease in the incidence of a marker encoding late migration [12]. Time-series data provides important insights into genetic responses to climate change. For example, Genotypic values for critical day length in the pitcher plant mosquitos (Wyeomyia smithii) were correlated with latitude. It was determined that the latitude relationship changed in the period from 1972 to 1996 [12]. Oceanic phytoplankton in the Gulf of Cariaco, Venezuela have been monitored for 15 years. In response to a temperature increase of $+0.73{ }^{\circ} \mathrm{C}$, phytoplactons adapted by adjusting their thermal niches to $+0.45^{\circ} \mathrm{C}$. [15]. Similarly, adaptation is possible in some reef corals [16]. These distribution shifts in population ranges create new "hybrid regions" at the global level. For example, hybrid zones between black-capped (Poecile atricapillus) and Carolina warbler (P. carolinensis) are changing in response to increases in winter temperatures in North America [17]. The southern flying squirrel (Glaucomys volans) has extended its range northward in Northeast America, and this species has interbred with the northern flying squirrel (G. sabrinus) to form a hybrid zone [18].

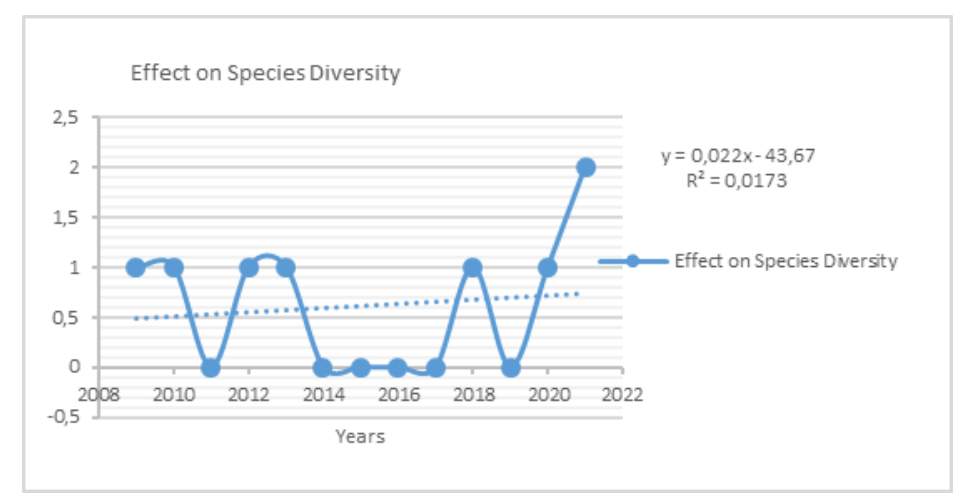

Figure 4. Publications on the impact of climate change on species diversity

Relatively few research have investigated the potential effects of climate on the spatial structure of genetic diversity and how population ranges change (fig. 5a). Similarly, in few studies have included intra-species relationships (fig. 5b). However, there has been a significant increase in these studies in recent years. This is an indication that intraspecific relationships are affected by genetic diversity. Some case studies support this situation.

The deep of genetic divergences in intraspecies lineages that widely distributed is remarkable. In this case, intraspecific relationship acted as a buffer against changes in the geographical structure [10]. In species with a strong 
phytogeographic cluster of gene diversity, the effects of climate change can be fairly different. The best example is seen in the study of New Zealand forest beetles (Agyrtodes labralis (Leiodidae), Brachynopus scutellaris (Staphylinidae) and Epistranus lawsoni (Zopheridae)) [6]. In the study, it was determined that Agyrtodes labralis will lose 50\% of its haplotypes by 2100 and its population distribution and current distribution areas will decrease. In Brachynopus scutellaris and Epistranus lawsoni species, little change in genetic diversity is expected. However, there will be expansion in climatically suitable areas. It is also expected that Brachynopus scutellaris populations will show phylogenetically more clustering by 2100 [6]. In the study on the South American treefrog Scinax squalirostris Lutz, it was determined that climate change will increase the geographical distribution range of the species and lead to homogenization [9]. This will also increase the genetic loss (5b). Another study explored effects of climate change on the phytogeographic distribution of European beech trees. In the species area models, it is estimated that the distribution of beech trees will expand towards the north and habitat loss will occur in the south.The effect of this change on genetic diversity is low $[19,20]$. The use of climate models and geographic information systems in determining the geographical distribution of species has resulted in increased interest in this area (5b).

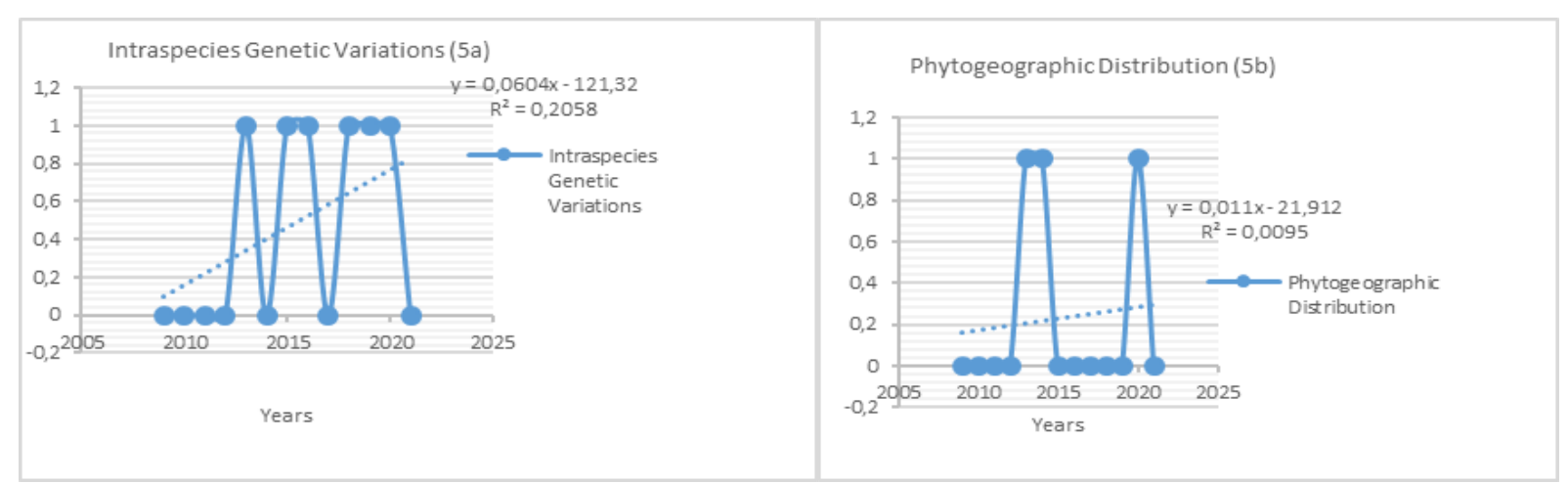

Figure 5a and 5b. Studies on intraspecies genetic variations and phytogeographic distribution

Climate change can also cause changes in gene flows. For example, chestnut crows (Garrulus glandarius) can cause gene flow between oaks and other tree populations. New individuals which join a population through migration may cause the gene frequency of the population to change. If gene flows that initially cause diversity continues long enough, they may reduce the differences between populations and cause neighbouring populations to form one population with the same genetic structure [21]. This is not a desired situation. Because this event causes a decrease in herorziot gene richness among populations. This leads to a decrease in adaptability and an increase in fragility and vulnerability in the population. It results in decreased biological richness and increased species and population losses.

Another threat to genetic diversity is invasive species. With the impact of climate change, it is inevitable that the number of invasive alien species will continue to increase, leading to the elimination of native species, which threatens especially rare and endemic species This affects local species more rapidly, especially populations and gene flows of endemic and rare species. Because rare and endemic species are vulnerable and fragile to the impacts of climate change. It is very difficult for these species to show genetic adaptation to changing climatic conditions. The most striking example of this is seen in the Mediterranean.

In the researches, it was revealed that the water temperature in the Mediterranean increased up to $32{ }^{\circ} \mathrm{C}$ with climate change, and therefore, the fish of the Red Sea spread to the Mediterranean water and created new ecosystems [22]. The tropicalization process has started with the increase in temperature, especially in the Eastern Mediterranean. Approximately 1000 invasive species have migrated to the Mediterranean so far. In some areas in the Mediterranean, stingrays have caused up to $40 \%$ reduction in the number of native species [23]. This situation poses a great threat especially to local gene resources and diversity.

\subsection{Models used to investigate the impact of climate change on genetic diversity}

Various modeling approaches are used to determine the relationships between genetic diversity and climate. Especially, ecological niche and species models have been combined with climate scenarios in recent years. In this way, current and future losses in genetic diversity, changes in geographical distribution and their effects on genetic diversity and variations are estimated (fig. 6). The results indicate that there is a positive linear relationship between modeling methods over time. It is also clear that there has been an increase in interest in this commune, especially in recent years. In studies using these modules, genetic losses due to climate change in the future, field shifts, have been revealed and mapped. These estimates play an important role in the concrete perception of genetic losses.

In recent years, It has been understood that climate is a significant abiotic factor that shapes genetic diversity within the species. Especially the models revealing habitat fragmentation, increasing range fragmentation and pieces distribution shifts a support this situation. However, while the number of researches investigating the effect of climate change on the gene diversity of species has increased, most of them have focused on a single plant or animal species at 
the geographical scale [24]. Ecological niche models are widely used to predict changes in the eco-geographical distribution of species due to climate change. This model uses the current distribution data of populations and species. It integrates these data into climate scenarios and predicts possible new eco-geographies for the future. In this way, the effect of spatial dynamics and changes on possible species distribution in the future is understood In these projections, it is assumed that the species protect their current ecological niche and will be able to follow suitable climatic conditions in future $[9,25]$.

In some studies, ecological niche models and population genetic approaches have been considered together. Thus, possible changes in genetic diversity can be projected into the future by using plastid and nuclear DNA. This provides information on whether species will generally lose their habitat range in the future. However, it is known that genetic homogeneity in the gene pool will become more pronounced in the future [25, 26]. Another model used is the species distribution model. This model focuses on species dynamics against the impact of climate change, especially in vulnerable populations [20].

Climate models are made for the years 2030, 2050, 2070 and 2100. Geographic information systems are generally used in these models based on scenario approach. With putative scenarios, maps are drawn about how species and genetic structures will follow in the future. For example, genomic and ecological modelling approaches have been used to describe climate-related genetic adaptations in two cryptic forest bats [10]. The data obtained were also used to predict the range changes directly resulted by future climate change. Population persistence was also assessed through the spread of climate-adapted genetic variation.

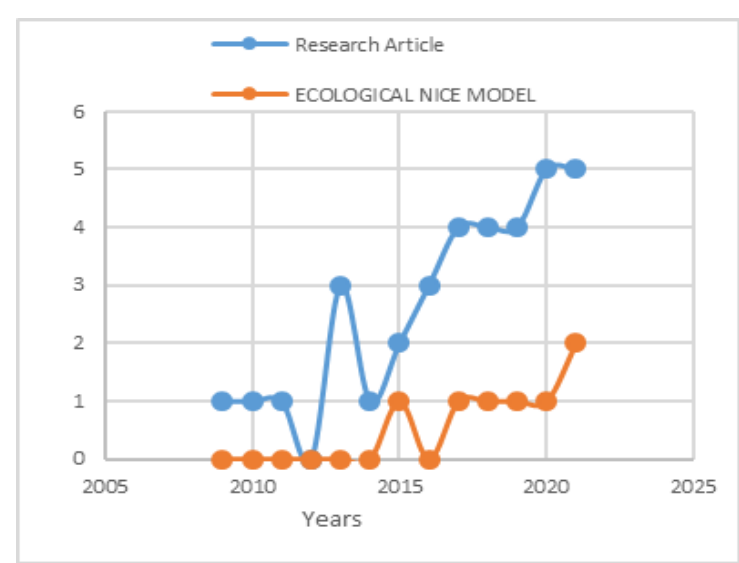

(a)

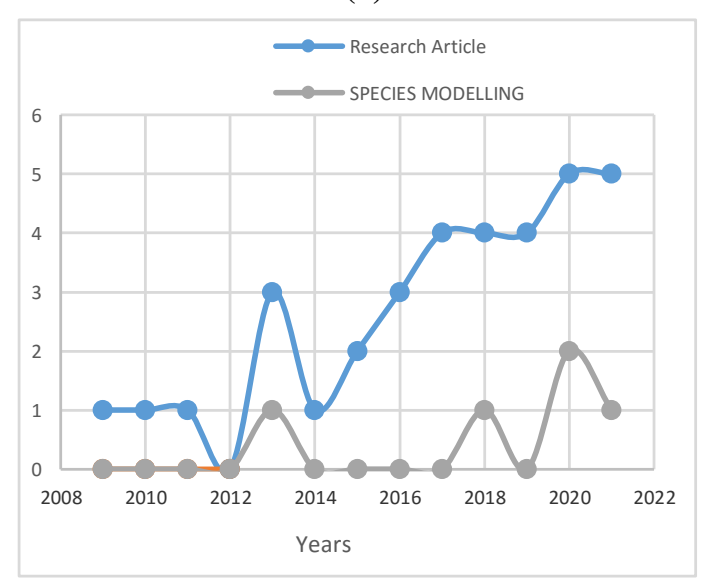

(c)

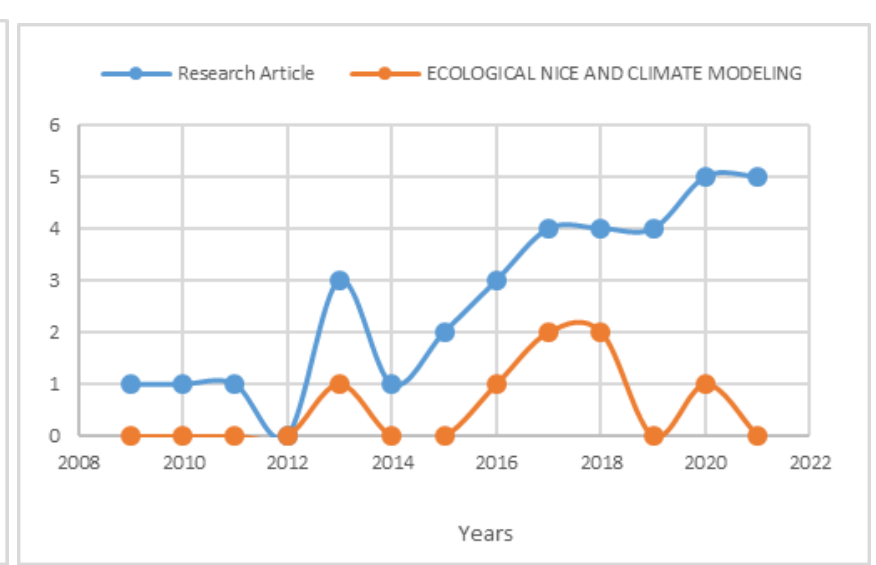

(b)

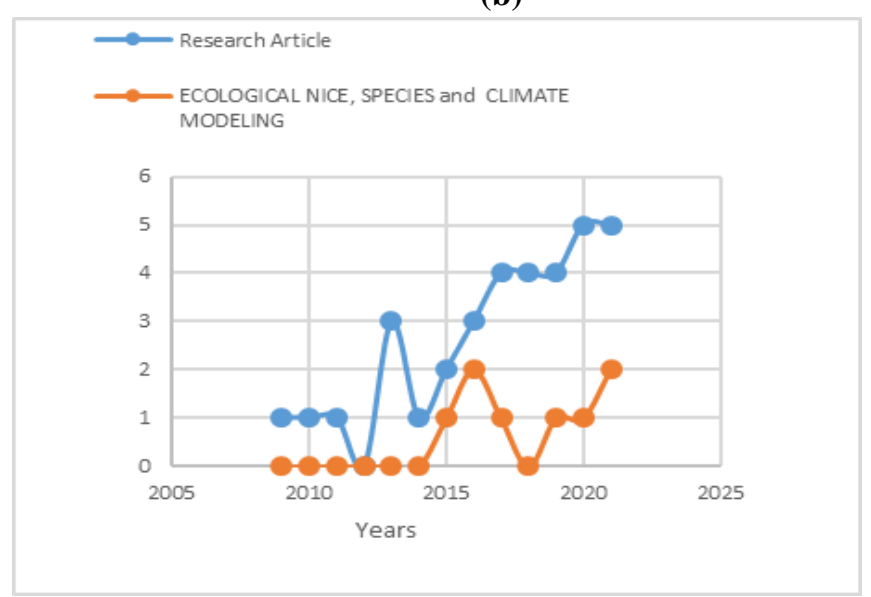

(d)

Figure 6. Distribution of models used to determine the relationships between genetic diversity and climate; (a) Ecological models, (b) Ecological and Climate models, (c) Species models, (d) Ecological, Species and Climate models

Gene diversity is significance for species to respond to climate change. Discovering relationships between gene diversity and factors of climatic might help estimate how climate change will shape the gene diversity of species in the future [22]. This allows us to understand how species will cope with changing climatic factors and to preserve the genetic diversity of species in the future.

\subsection{Evaluation of studies on the conservation of genetic diversity}


Gene diversity is critical for species to evolve and adapt to new conditions, as well as for ecosystem recovery and populations responses to environmental changes. Therefore, understanding the effects of climate change on genetic diversity is of great importance for species protection, especially rare and endangered species conservation and recovery [24]. In research results, studies on the conservation of genetic diversity have increased especially after 2016. This situation shows that there is a positive correlation between recent years and studies that include measures for the protection of genetic diversity and reveal its importance (Figure 7). At the same time, these studies reveal that genetic losses should not be neglected in climate change studies.

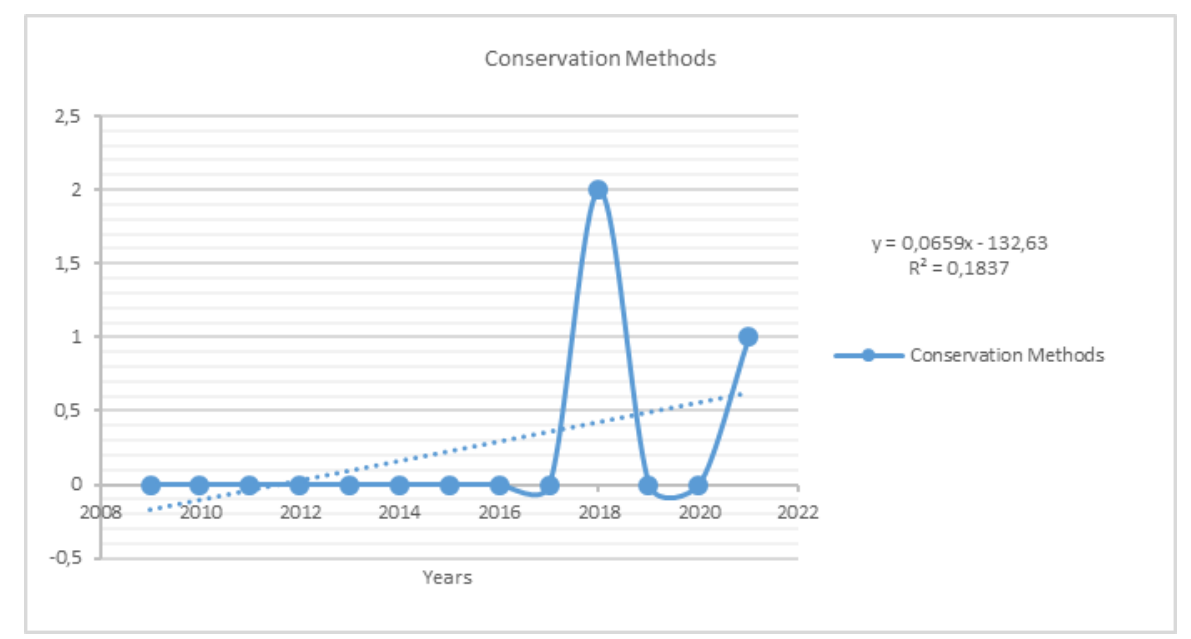

Figure 7. Correlation curve for conservation of genetic diversity

Climate models have shown that future space changes will be limited by interspecies competition. However, this depends on the adaptive capacity of the population. This is associated with genetic variations [22]. Resources show that native adaptations are neglected in the estimates of species fragility and extinction risks. However, incorporating local adaptations into modelling estimates reduces habitat losses [10]. It also increases the effectiveness of protection measures. Taking insuti and exsuti protection measures against field change, creating protected areas and adopting process-based models are significant in the protection of genetic diversity. Considering the fragility of local, rare and endemic genetic resources, the importance of this issue increases even more.

\section{Conclusions and discussion}

As a result, revealing the relationships between climate and genetic diversity is important in the conservation and transfer of genetic diversity to the future. Thus, using ecological models together with climate models will more clearly explain the effect of climate on genetic diversity. Climate analysis and mapping of all global species and populations will enable conservation measures to be developed and managed. Losses in genetic diversity levels at local, regional, national, and global levels should be mapped, integrated with bioclimatic models and a global database should be created. To prioritize populations and species for conservation, it is critical to generate reliable predictions about the adaptive portrait. Taking green protection measures based on innovation technologies will play an important role in reducing the impact of climate change on living things. Especially for endemic and rare species, "integrated approaches based on ecology" should be developed at the global level.

\section{References}

[1] Alsos, G.J., Ehrich, D., Thuiller, W., Eidesen, B.P., Tribsch, A., Scho"nswetter, P., Lagaye, C., Taberlet, P., \& Brochmann, C. (2012). Genetic consequences of climate change for northern plants. Proceedings of the Royal Society B, 279, 2042-2051 doi:10.1098/rspb.2011.2363

[2] Tolunay, D. (2019). İklim Değişikliğinin Ekolojik Sistemlerdeki Yeri. İklim Değişikliği Eğitim Modülleri Serisi 5, Ankara.

[3] Warren, R., \& Warren, R.J. (2013). Unauthorized Immigration to the United States: Annual Estimates and Components of Change, by State, 1990 to 2010. International Migration Review, 47, $296-329$. http://dx.doi.org/10.1111/imre.12022

[4] Ramirez-Villegas, J., Cuesta, F., Devenish, C., Peralvo, M., Jarvis, A., \& Arnilla, A.C. (2014). Using species distributions models for designing conservation strategies of Tropical Andean biodiversity under climate change. Journal for Nature Conservation, 22, 391-404. 
[5] IPCC (2021). IPCC report: 'Code red' for human driven global heating, warns UN chief. Access date 18.11.2021 https://news.un.org/en/story/2021/08/1097362

[6] Pärli, R., Lieberherr, E., Holderegger, R. Gugerli, F., Widmer, A., Fischer, C.M. (2021). Developing a monitoring program of genetic diversity: what do stakeholders say? Conservation Genetics, 22, 673-68

[7] Demir, A. (2009). Küresel iklim değişiminin biyolojik çeşitlilik ve ekosistem kaynakları üzerine etkisi. Ankara Üniversitesi Çevre Bilimleri Dergisi, 1(2), 37-54

[8] Rizvanovic, M., Kennedy, D.J., Nogués-Bravo, D., \& Marske, A.K. (2019). Persistence of genetic diversity and phylogeographic structure of three New Zealand Forest beetles under climate change. Diversity and Distributions, 25, 142-153. DOI: 10.1111/ddi.12834

[9] Abreu-Jardim, F.P.T., Jardim, L., Ballesteros-Mejia, L., Maciel, M.N., \& Collevatti, G.R. (2021). Predicting impacts of global climatic change on genetic and phylogeographical diversity of a Neotropical treefrog. Diversity and Distributions, 27, 1519-1535

[10] Razgoura, O., Foresterc, B., Taggartd, B.T., Bekaertd, M., Justee, J., Ibáñeze, C., Puechmaillef, J.S, NovellaFernandeza, R., Alberdii, A., \& Manelj, S. (2019). Considering adaptive genetic variation in climate change vulnerability assessment reduces species range loss projections. PNAS, 116 (21), 10418-10423

[11] Scheffers, R.B., De Meester, L., C. L. Bridge, L.C.T., Hoffmann, A.A., Pandolfi, M.J., Corlett, T.R., Butchart, M.H.S., Pearce-Kelly, P., Kovacs, M.K., Dudgeon, D., Pacifici, M., Rondinini, C., Foden, B.W., Martin, G.T., Mora, C., Bickford, D., \& Watso, M.E.J. (2016). The broad footprint of climate change from genes to biomes to people. Science, 354, 767. DOI: 10.1126/science.aaf7671

[12] De Meester, L., Stoks, R., \& Brans, I.K. (2018). Genetic adaptation as a biological buffer against climate change: Potential and limitations. Integrative Zoology, 13, 372-39

[13] Thomann, M., Imbert, E., Engstrand, C.R., \& Cheptou O.P. (2015). Contemporary evolution of plant reproductive strategies under global change is revealed by stored seeds. Journal of Evolutionary Biology, 28, 766-778. doi: 10.1111/jeb.12603

[14] Kovach, R.P., Gharrett, A.J., \& Tallmon, D.A. (2012). Genetic change for earlier migration timing in a pink salmon population. Proceedings of the Royal Society B: Biological Sciences, 279, 3870-3878. doi: 10.1098/ rspb.2012.1158; pmid: 22787027

[15] Irwin, J.A., Finkel, V.Z., Müller-Karger, E.F., \& Troccoli Ghinaglia, L. (2015). Phytoplankton adapt to changing ocean environments. Proceedings of the National Academy of Sciences, 112, 5762-5766. doi: 10.1073/pnas.1414752112; pmid: 25902497

[16] Palumbi, S.R., Barshis, J.D., Traylor-Knowles, N., \& Bay, A.R. (2014). Mechanisms of reef coral resistance to future climate change. Science, 344, 895-898

[17] Taylor, A.S., White, A.T., Hochachka, H.M., Ferretti, V., Curry, L.R., \& Lovette, I. (2014). Climate-mediated movement of an avian hybrid zone. Current Biology, 24, 671-676. doi: 10.1016/ j.cub.2014.01.06

[18] Garroway. J.C., Bowman, J., Cascaden, J.T., Holloway, L.G., Mahan, G.C., Malcolm, R.J., Msteele, A.M., Turner, G., \& Wilson, J.P. (2010). Climate change induced hybridization in flying squirrels. Global Change Biology, 16, 113-121. doi: 10.1111/j.1365-2486.2009.01948.x

[19] Kramer, K., Degen, B., Buschbom, J., Hickler, T., Thuiller, W., Sykes, T.M., \& de Winter, W. (2010). Modelling exploration of the future of European beech (Fagus sylvatica L.) under climate change-Range, abundance, genetic diversity and adaptive response. Forest Ecology and Management, 259, 2213-2222

[20] Diniz-Filho, F.A.J., Barbosa, F.O.C.A., Chaves, J.L., Souza, S.K., Dobrovolski, R., Rattis, L., Terribile, C.L, Lima-Ribeiro, S.M., de Oliveira, G., Brum, T.F., Loyola, R., \& Telles, C.P.M. (2020). Overcoming the worst of both worlds: integrating climate change and habitat loss into spatial conservation planning of genetic diversity in the Brazilian Cerrado. Biodiversity and Conservation, 29, 1555-1570

[21] Doğan, S., Özçelik, S., Dolu, Ö., \& Erman, O. (2010). Global warming and biodiversity. İklim Değişikliği ve Çevre, 3

[22] Sękiewicz, K., Walas, L., Beridze, B, Fennane, M., \& Dering, M. (2020). High genetic diversity and low future habitat suitability: will Cupressusa atlantica, endemic to the High Atlas, survive under climate change? Regional Environmental Change, 20(132), 2-19

[23] WWF (2021). İklim Değişikliğinin Akdeniz'deki Etkileri; Aşırı ısınan bir denizden altı hikaye. WWF 2021 raporu. Access date: https://wwftr.awsassets.panda.org/downloads/iklim_deiiklii_nin_akdeniz_deki_etkileweb.pdf

[24] Jingfang, T., Jizhong, W., Fangli, L., \& Feiha, Y. (2018). Relationships between Genetic Diversity of Vascular Plant Species and Climate Factors. Journal of Resources and Ecology, 9(6), 663-672. DOI: 10.5814/j.issn.1674$764 \mathrm{x}$

[25] Wróblewska, A., \& Mirski, P. (2018). From past to future: impact of climate change on range shifts and genetic diversity patterns of circumboreal plants. Regional Environmental Change, 18, 409-424. DOI 10.1007/s10113017-1208-3

[26] Raza, A., Razzaq, A., Mehmood, S.S., Zou, X., Zhang, X., Lv, Y., \& Xu, J. (2019). Impact of Climate Change on Crops Adaptation and Strategies to Tackle Its Outcome: A Review. Plants, 8, 34. doi:10.3390/plants8020034 